\title{
The Caddoan Oak Hill Village Site
}

\section{J. Brett Cruse \\ Texas Historical Commission}

Timothy K. Perttula

Heritage Research Center, Stephen F. Austin State University

Follow this and additional works at: https://scholarworks.sfasu.edu/ita

Part of the American Material Culture Commons, Archaeological Anthropology Commons, Environmental Studies Commons, Other American Studies Commons, Other Arts and Humanities Commons, Other History of Art, Architecture, and Archaeology Commons, and the United States History Commons

Tell us how this article helped you.

This Article is brought to you for free and open access by the Center for Regional Heritage Research at SFA ScholarWorks. It has been accepted for inclusion in Index of Texas Archaeology: Open Access Gray Literature from the Lone Star State by an authorized editor of SFA ScholarWorks. For more information, please contact cdsscholarworks@sfasu.edu. 


\section{The Caddoan Oak Hill Village Site}

Creative Commons License

(c) (i) (8)

This work is licensed under a Creative Commons Attribution-NonCommercial 4.0 International License 


\section{THE CADDOAN OAK HILL VILLAGE SITE}

\section{J. Brett Cruse and Timothy K. Perttula}

Rarely do prehistoric archeologists in North America have the opportunity to completely excavate and study an entire Native American community or village. To be able to expose a Native American village in its entirety provides a unique, and unprecedented, view of the past community and social arrangements that existed among Native American societies before contact with Europeans.

Recently, in northeast Texas, the Oak Hill Village site (41RK214), a large village occupied by prehistoric horticultural-agricultural Caddo peoples between about A.D. 1050 and 1450, was fully uncovered under the direction of J. Brett Cruse (then of Espey, Huston \& Associates, Inc., Austin, Texas) for Texas Utilities Services (TU Services; Cruse 1995). The company plans to strip mine the site area in the near future for lignite coal. With the cooperation of TU Services, the investigations at the Oak Hill Village were the most extensive ever completed at a Caddo Indian site.

The Oak Hill Village lies on a long, narrow ridge overlooking the floodplain of Mill Creek, a secondary tributary of the Sabine River. The main channel of the creek, which flows north some $20 \mathrm{~km}$ to the Sabine River, is ca. 400 meters to the west of the site.

The January 1994 through May 1995 excavations documented the remains of 42 structures, probably grass-thatched, and 165 features (Figure 1), along with abundant artifacts and preserved plant remains (mostly maize). Over 25,000 ceramic sherds were recovered at the Oak Hill Village. These abundant artifacts and features indicated the domestic use of the village.The features included smudge pits filled with charred corn cobs, storage pits, hearths, and three Caddo burials. The structures and features are arranged in a roughly circular fashion around the edges of the ridge top, leaving a large open area, or plaza, in the center. There was no palisade or fortification around the village.

The entrances to most of the structures were oriented so that they open into the plaza. This large plaza area was free of artifacts and features, and it is likely that it was primarily used for communal activities and ceremonies. This would have included dancing, as suggested to us by Cecile Elkins Carter, Cultural Representative of the Caddo Tribe of Oklahoma.

Among the structures were 33 large (six to 10 meters in diameter) circular structures that represent Caddo houses for single and/or extended families. Two of these had extended entranceways marked with posts (Figure 2). Most of the structures had central posts, but lacked evidence of central clay-lined hearths. Three large rectangular-shaped structures (ca. 11 meters long and seven to eight meters wide), also residences, were discovered in the northwestern part of the community. Many of the structures and structure posthole patterns overlap each other, indicating that houses were rebuilt in favored locales (Figure 1). The two largest rectangular structures underlaid a number of the circular structures. Six small circular structures, two to three meters in diameter) are clustered along the eastern edge of the site, away from most of the household compounds (Figure 1). We think it probable that these small structures were aboveground storage facilities, perhaps granaries, as were common among the Caddo in historic times. Thus, the area containing these structures may represent a communal storage area. 


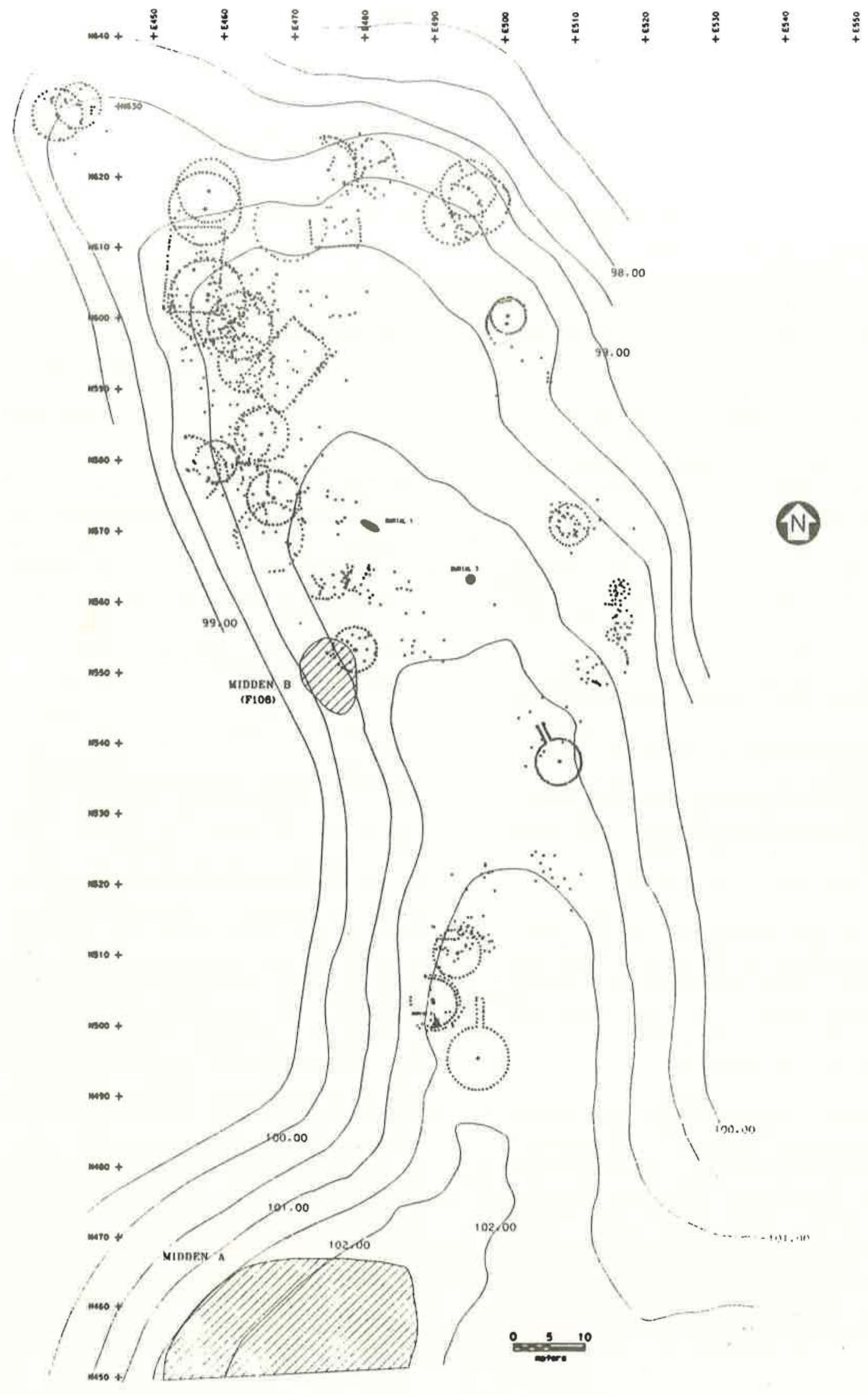

Figure 1. Oak Hill Village Site (41RK214), Plan Topographic Map. 
The spatial arrangement of the structures and open space show that the prehistoric Caddo who lived at the Oak Hill Village apparently maintained a stable organization of their domestic, public, and communal activities over a period perhaps lasting as long as 400 years. Hence, over a considerable span of time, the village retained its basic layout as a functioning Caddo community.

\section{References Cited}

Cruse, J. Brett

1995 Archaeology at the Oak Hill Village Site:

A Caddoan Settlement in Rusk County.

Heritage 13(1):10-14. Texas Historical

Foundation, Austin.

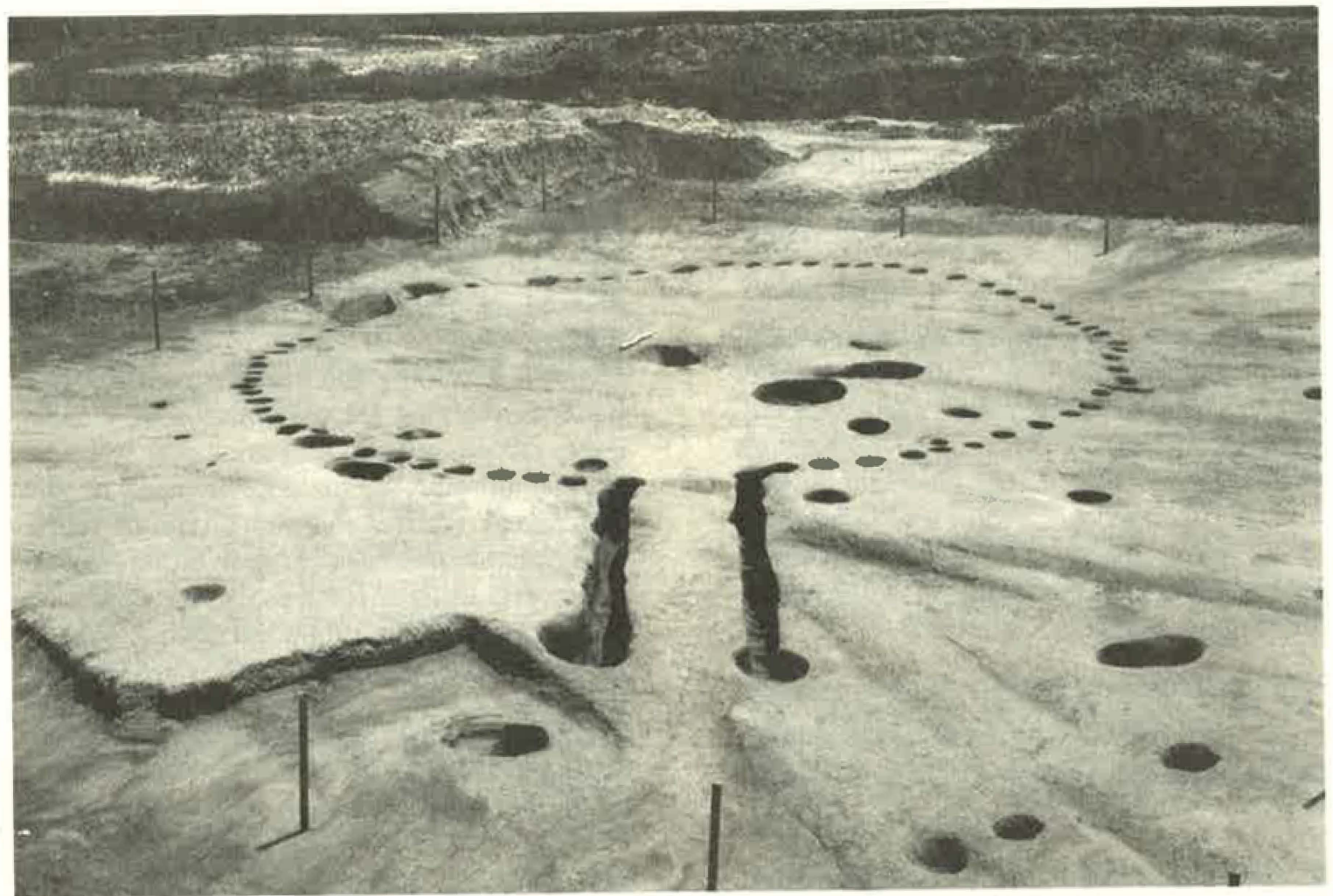

Figure 2. Photograph of Structure 2 Posthole Pattern. 